\title{
Monitoring of Glycation, Oxidative Stress and Inflammation in Relation to the Occurrence of Vascular Complications in Patients With Type 2 Diabetes Mellitus
}

\author{
V. JAKUŠ ${ }^{1}$, E. ŠÁNDOROVÁ ${ }^{1}$, J. KALNINOVÁ ${ }^{1}$, B. KRAHULEC ${ }^{2}$ \\ ${ }^{1}$ Institute of Medical Chemistry, Biochemistry and Clinical Biochemistry, Faculty of Medicine, \\ Comenius University, Bratislava, ${ }^{2}$ Second Department of Internal Medicine, University Hospital, \\ Faculty of Medicine, Comenius University, Bratislava, Slovak Republic
}

Received September 27, 2013

Accepted December 13, 2013

On-line February 24, 2014

\begin{abstract}
Summary
The study aimed to evaluate if the monitoring of advanced glycation end products (AGEs), advanced oxidation protein products (AOPP), lipoperoxides (LPO) and interleukin-6 (IL-6) in plasma could help to predict development of diabetic complications (DC). Clinical and biochemical parameters including AGEs, AOPP, LPO and IL- 6 were investigated in patients with type 2 diabetes mellitus (DM2) with (+DC) and without (-DC) complications. AGEs were significantly higher in both diabetic groups compared to controls. AGEs were also significantly higher in group +DC compared to -DC. AGEs significantly correlated with HbA1c. We observed significantly higher AOPP in both diabetic groups in comparison with controls, but the difference between $-D C$ and +DC was not significant. LPO significantly correlated with BMI. IL- 6 were significantly increased in both diabetic groups compared to controls, but the difference between $-D C$ and $+D C$ was not significant. There was no significant correlation between IL- 6 and clinical and biochemical parameters. These results do not exclude the association between IL- 6 and onset of DC. We suggest that the measurement of not only $\mathrm{HbA1C}$, but also AGEs may be useful to predict the risk of DC development in clinical practice. Furthermore, the measurement of IL- 6 should be studied as adjunct to HbA1c monitoring.
\end{abstract}

\section{Key words}

Advanced glycation • Oxidative stress • Inflammation • Diabetic complications • Type 2 diabetes mellitus

\section{Corresponding author}

Vladimír Jakuš, Institute of Medical Chemistry, Biochemistry and
Clinical Biochemistry, Faculty of Medicine, Comenius University, Sasinkova 2, 81108 Bratislava, Slovak Republic. Fax: +421-259357557. E-mail: vladimir.jakus@fmed.uniba.sk

\section{Introduction}

Over the last few years the number of people with type 2 diabetes mellitus (DM2) has massively increased, becoming one of the most important public health challenges globally. Diabetic complications (DC) are now a global health problem without effective therapeutic approach (Singh et al. 2013). Recently, major advances have been made in understanding the mechanisms that are involved in the pathogenesis of DM2 (Barbarroja et al. 2012).

Chronic hyperglycemia is a major etiological factor causing both micro- and macrovascular lesions associated with DM2 (Paneni et al. 2013). Numerous biochemical changes initiated by hyperglycemia directly influence cellular function and lead to abnormal vascular remodeling and the development of vascular and other DC (Wadham et al. 2007, Miller et al. 1996). Long-term hyperglycemia is linked with early, intermediate and advanced glycation, glycoxidation, oxidative stress and low-grade inflammation (Wiliams and Nadler 2007, Aronson 2008, Negre-Salvayre et al. 2009, Garcia et al. 2010, Navale and Paranjape 2013). However, the interrelationship between advanced glycation, oxidative stress, inflammation and the progression of vascular DC have not been fully understood (Bigagli et al. 2012). Levels of 
early glycation product - glycated hemoglobin ( $\mathrm{HbAlc})$ predict potential diabetic micro- and macrovascular DC (Zoungas et al. 2012, Rácz et al. 2012, Higgins 2013). Higher HbAlc levels are also associated with higher levels of markers of inflammation (de Rekeneire et al. 2006).

Elevated levels of glucose accelerate the formation of advanced glycation end-products (AGEs). AGEs are produced through the nonenzymatic glycation and oxidation of proteins, lipids and nucleic acids (Jakuš and Rietbrock 2004, Giacco and Brownlee 2010). These compounds derive from both endogenous and exogenous sources, and take effect at both intracellular and extracellular level. AGEs excess is one of the most important mechanisms involved in the pathophysiology of chronic vascular DC. An excessive AGE formation has been demonstrated in the newly disclosed biochemical pathways involved in the microvascular pathobiology of DM2 (Chen et al. 2013, Chilleli et al. 2013). AGEs are also believed to have a key role in the development and progression of cardiovascular disease in patients with DM2 (Hegab et al. 2012). Via their chief signaling receptor - the AGE-specific receptor (commonly abbreviated as RAGE) AGEs generate reactive oxygen species (ROS) and activate inflammatory signaling cascades (Yan et al. 2008, Yamamoto and Yamamoto 2013). RAGE has a dual function and it is involved in both AGE removal and AGE-induced cell activation (Motawi et al. 2013). Cell activation can occur via receptor-mediated generation of ROS through both mitochondrial and cytosolic pathways involving the electron transport chain and nicotinamide adenine dinucleotide phosphate-oxidase (NADPH oxidase), respectively. ROS can trigger pro-inflammatory signaling pathways causing mitogen-activated protein kinasedependent (MAPK-dependent) activation of transcription factors such as nuclear factor kappa B (NF-kB) and consequent increased cytokine and adhesion molecules expression, induction of oxidative stress, and an increase in cytosolic ROS (Calder et al. 2011, Piarulli et al. 2013).

From markers of oxidative stress advanced oxidation protein products (AOPP) have emerged as a novel class of inflammatory mediators. AOPP are the dityrosine-containing and cross-linking protein products formed during oxidative stress (Kalousová et al. 2002). In DM2 the formation of AOPP is induced by intensified glycoxidation processes, oxidant-antioxidant balance, and coexisting inflammation (Piwowar et al. 2007). Data suggest that chronic accumulation of AOPP in plasma may promote renal inflammation in DM2 patients probably through activation of renal NADPH oxidase (Shi et al. 2008) and are associated with increased susceptibility to develop diabetic retinopathy (AlShabrawey and Smith 2010, Chen et al. 2013).

Other markers of oxidative stress are lipoperoxides (lipid hydroperoxides) (LPO). LPO are generated from polyunsaturated fatty acids and represent primary end products of the lipoperoxidation. Lipoperoxidation is a cascade of events resulting from the action of ROS on polyunsaturated fatty acids present in cell membranes (Bandeira et al. 2013). Circulating LPO levels have been shown to be significantly elevated in association with myocardial ischemia and cardiovacsular risk factors (Walter et al. 2008). Lipoperoxidation is increased in DM2 patients and may be related to modulation of the inflammatory response (Bastos et al. 2012, Yadav and Ramana 2013).

Inflammation is thought to mediate pancreatic $\beta$ cell dysfunction and the development of insulin resistance (Wiliams and Nadler 2007). Insulin resistance leads to a perturbation in the lipid homeostasis, cytokines, and adipokines production, resulting in increased systemic inflammation, with higher levels of inflammatory markers such as $\mathrm{C}$-reactive protein (CRP), tumor necrosis factor- $\alpha$ (TNF- $\alpha$ ), and interleukin 6 (IL-6) (Garcia et al. 2010, Pedicino et al. 2013). Elevated serum IL-6 levels have been found to be associated with insulin resistance and increased risk of DM2 (Wang et al. 2013). In chronic hyperglycemia, cytokines infiltrate vascular tissues and inhibit function and repair. Studies in recent years have shown that inflammation, and more specifically proinflammatory cytokines, are the determinants in the development of micro- and macrovascular DC (Mora et al. 2006, Jeffcoate et al. 2006, Mocan et al. 2006, King 2008, Wu et al. 2012, Navale and Paranjape 2013). Numerous efforts have gained way to understanding the mechanisms of the inflammatory response, however, effective treatments have still not emerged (Nguyen et al. 2012).

The aim of the present study was evaluated if monitoring of circulating $\mathrm{HbAlc}$, plasma levels of AGEs, AOPP, LPO and IL-6 in patients with DM2 could help to predict the DC development. 
Table 1. Baseline characteristic of diabetic patients and controls.

\begin{tabular}{|c|c|c|c|c|}
\hline Parameter & $\begin{array}{l}\text { DM2 patients } \\
(\mathrm{n}=81)\end{array}$ & $\begin{array}{l}\text {-DC group } \\
(n=26)\end{array}$ & $\begin{array}{l}+D C \text { group } \\
(n=55)\end{array}$ & $\begin{array}{l}\text { Controls } \\
(n=20)\end{array}$ \\
\hline Age (years) & $63 \pm 9.6^{3}$ & $58.3 \pm 9.6^{2}$ & $65.2 \pm 8.8^{1,3}$ & $54.2 \pm 6.6$ \\
\hline Weight (kg) & $89.97 \pm 16.42$ & $92.10 \pm 19.17$ & $88.97 \pm 14.04$ & $82.85 \pm 19.38$ \\
\hline$B M I\left(\mathrm{~kg} / \mathrm{m}^{2}\right)$ & $30.89 \pm 5.40$ & $32.18 \pm 6.01^{3}$ & $30.26 \pm 5.02$ & $28.41 \pm 5.06$ \\
\hline Waist circumf. $(\mathrm{cm})$ & $104.9 \pm 13.5^{3}$ & $105.0 \pm 13.8$ & $104.9 \pm 13.5^{3}$ & $96.9 \pm 13.99$ \\
\hline DM2 duration (years) & $12.6 \pm 7.0$ & $8.5 \pm 4.4$ & $14.6 \pm 7.2$ & - \\
\hline Smokers $(n)$ & $19(24)$ & $6(23)$ & $13(24)$ & $2(10)$ \\
\hline Lipid or TC lowering drugs $n(\%)$ & $56(69)$ & $16(62)$ & $40(73)$ & - \\
\hline Antihypertensive drugs $n(\%)$ & $61(75)$ & $18(69)$ & $43(78)$ & - \\
\hline Only diet $n(\%)$ & $3(4)$ & $1(4)$ & $2(4)$ & - \\
\hline$O A D n(\%)$ & $38(47)$ & $18(69)$ & $20(36)$ & - \\
\hline$O A D$ and diet $n(\%)$ & $8(10)$ & $6(23)$ & $2(4)$ & - \\
\hline Insulin and $O A D n(\%)$ & $22(27)$ & $1(4)$ & $21(38)$ & - \\
\hline Insulin $n(\%)$ & $10(12)$ & $0(0)$ & $10(18)$ & - \\
\hline
\end{tabular}

DM2 patients - patients with type 2 diabetes mellitus, $-\mathrm{DC}$ - diabetic patients without diabetic complications, +DC - diabetic patients with diabetic complications, Controls - control group, BMI - body mass index, DM2 duration - duration of type 2 diabetes mellitus, waist circumf. - waist circumference, TC - total cholesterol, OAD - oral anti-diabetic agents, $\mathrm{n}$ - number of subjects per group, \% percentage of subjects per group. Data are presented as means $\pm S$. D. of $n=81$ diabetics patients $(-D C n=26,+D C n=55)$ and $n=20$ controls. ${ }^{1} p<0.05$ compared to group $-D C,{ }^{2} p<0.05$ compared to group $+D C,{ }^{3} p<0.05$ compared to controls

\section{Materials and Methods}

\section{Patients and the sample collection}

The study was approved by Local Ethical Committee. Blood, serum/plasma were obtained from 81 patients (49 men, 32 women; age: $63 \pm 9.6$ years) suffering from DM2, regularly attending the Second Department of Internal Medicine, Comenius University in Bratislava, Slovakia. Venous blood samples were collected after 12-h overnight fasting. Within $1 \mathrm{~h}$ of collection, blood was centrifuged (1200 x g, $10 \mathrm{~min})$, serum and plasma (EDTA as an anticoagulant) were obtained. Aliquoted biological samples were frozen for later investigation. Blood plasma and serum were kept at $-80{ }^{\circ} \mathrm{C}$.

Criteria for inclusion/exclusion of patients were as follows: included patients were nonpregnant, and nonlactating women, without cancer and without mental health problems (senile dementia and Alzheimer's disease, among others) and without secondary diabetes. Twenty-six patients were without diabetic complications (-DC group; 13 men and 13 women; age: $58.3 \pm 9.6$ years) and 55 patients were with micro- or macrovascular complications (+DC group; 36 men and 19 women; age: $65.2 \pm 8.8$ years). Microvascular complications included diabetic retinopathy, nephropathy and neuropathy.
Diabetic retinopathy was diagnosed through fundus examination performed by an ophthalmologist, while nephropathy was defined on the basis of at least two values of albumin/creatinine ratio $>30 \mathrm{mg} / \mathrm{g}$ (NICE Clinical Guidelines, No. 73, 2008). Diabetic neuropathy was confirmed by electromyography (EMG) exploration using the conductivity assessment of sensor and motor fibers of peripheral nerves. Macrovascular complications were defined as follows: myocardial infarction (documented history of myocardial infarction, and/or electrocardiographic and echocardiographic evidence of myocardial necrosis); stroke (documented history of previous stroke requiring hospitalization, including minor stroke); peripheral artery disease (history of gangrene, or ankle-brachial index $<0.7$ with signs of atherosclerosis of arteries of lower limbs at the echo-color Doppler examination) (Carman and Fernandez 2000, Khan et al. 2008). From all enrolled patients, 38 were treated with only oral anti-diabetic agents (OAD), 8 with OAD and were on a diet, 22 with combination insulin and OAD and 10 only with insulin. Furthermore, 56 patients were also being treated with lipid or cholesterol lowering drugs and 61 with antihypertensive drugs (Table 1). 20 healthy blood volunteers without diabetes or other metabolic diseases ( 8 men and 12 women; age: 54.2 \pm 6.6 years) were used as controls. 19 diabetic patients and 2 controls 
were smokers. None of diabetic patients and controls were taking any additional antioxidants and individually antioxidant supplements. All participants were fully informed and gave written consent.

\section{Clinical and anthropometric assessment}

Resting systolic (SBP) and diastolic (DBP) blood pressure levels were measured in the left arm in the sitting position by sphygmomanometer (Omron M3, Intellisense, Japan). Body weight and height were measured without shoes and with light clothing using a digital weighing and measuring station with automatic body mass index (BMI) calculation $\left(\mathrm{kg} / \mathrm{m}^{2}\right.$, SECA 764, Germany). Waist circumferences were measured in $\mathrm{cm}$ with an inelastic tape to the nearest $\mathrm{mm}$, with the subject in a standing position.

\section{Determination of basic biochemical parameters}

Basic biochemical parameters were measured by using standard biochemical procedures at the Biochemical Clinical Laboratory of the University Hospital, Comenius University, Bratislava; and the results were identified with the use of reference ranges in this laboratory. Fasting blood glucose was measured by commercially available kit by glucose oxidase method using Hitachi 911 Analyzer (Roche Diagnostics, Switzerland). HbA1c was determined by HPLC (DiaStat, Bio-RAD, USA) in fair capillary blood using the IFCC calibration. Serum total cholesterol (TC), triacylglycerols (TAG), LDL-cholesterol (LDL) and HDL-cholesterol (HDL) were estimated from serum enzymatically and colorimetrically using automatic analyser Cobas Integra 400 (Roche, Switzerland). Serum creatinine was estimated using an enzymatic method (Vitros 250, Johnson and Johnson Company, USA).

\section{Determination of AGEs in plasma}

Determination of AGEs in plasma (i.e. some fluorescent products from the family of AGEs) was based on the spectrofluorimetric detection according to Henle et al. (1999) and Munch et al. (1997) in modification Kalousová et al. (2001). Blood plasma was diluted 1:40 with PBS pH 7.4 and fluorescence intensity was recorded at the emission maximum at $440 \mathrm{~nm}$ upon excitation at $345 \mathrm{~nm}$ (spectrofluorimeter Perkin Elmer LS 45). Fluorescence intensity was expressed in AU/g protein.

\section{Determination of AOPP in plasma}

AOPP were determined in the plasma using the method previously described by Witko-Sarsat et al.
(1996) and modified by Kalousová et al. (2001). AOPP were quantified by spectrophotometry (GEN5 Elisa from Biotek, USA) at $340 \mathrm{~nm}$ after incubation of samples with acetic acid using chloramin $\mathrm{T}$ with potassium iodide for the calibration curve. Concentration of AOPP in the sample was expressed in $\mu \mathrm{mol} / 1$.

\section{Determination of LPO in plasma}

LPO in plasma were determined as described by El Saadani et al. (1989) and modified by Sumegová et al. (2006). Determination is based on the ability of peroxide to oxidize iodide $\left(\mathrm{I}^{-}\right)$to iodine $\left(\mathrm{I}_{2}\right)$. Iodine in the reaction mixture then reacts with excess iodide to form $\mathrm{I}_{3}$ with the absorption maximum at a wavelength of $365 \mathrm{~nm}$. Absorbance was measured in a narrow cell in the dualbeam spectrophotometer PharmaSpec Shimadzu UV1700 at $365 \mathrm{~nm}$. All results were presented in $\mathrm{nmol} / \mathrm{ml}$ of sample.

\section{Determination of IL-6 in plasma}

Plasma levels of IL- 6 were determined using Fluorokine MAP cytokine multiplex kit designed for use with Luminex ${ }^{\circledR} 100^{\mathrm{TM}}$ analyzer produced at R\&D Systems (Minneapolis, MN, USA) according to the manufacturer's instructions. The cytokine was analyzed using $\mathrm{xMap}^{\mathrm{TM}}$ technology which combines the principle of a sandwich immunoassay with fluorescent-bead-based technology allowing multiplex analysis of up to 100 different analytes in a single microtiter well (Vignali 2000). Analysis of data was done using four-parametric-curve fitting (Little 2004). Results were presented in $\mathrm{pg} / \mathrm{ml}$.

\section{Statistics}

Clinical and biochemical parameters of the patients and controls were compared using the Student's t-test and were expressed as means \pm S.D. values. Results without normal distribution were statistically processed by Kruskal-Wallis test and the Connover Inmann post hoc test. Normality of data distribution was tested using the Shapiro-Wilk test. The correlation between measured parameters was examined using the Pearson's correlations test or Spearman's rank correlation test. For evaluation of the relationship between AGEs and clinical and biochemical parameters a multivariate linear regression analysis was used. For statistical analysis we employed the statistical program StatsDirect v. 2.3.7 (StatsDirect Sales, Sale, UK). For graphical representation of data we used Excel 2000 (Microsoft Co.). P values less than 0.05 were accepted as being statistically significant. 
Table 2. Biochemical parameters of diabetic patients and controls.

\begin{tabular}{|c|c|c|c|c|}
\hline Parameter & $\begin{array}{l}\text { DM2 patients } \\
(\mathrm{n}=\mathbf{8 1})\end{array}$ & $\begin{array}{l}\text {-DC group } \\
(n=26)\end{array}$ & $\begin{array}{l}+ \text { DC group } \\
(n=55)\end{array}$ & $\begin{array}{l}\text { Controls } \\
(n=20)\end{array}$ \\
\hline $\mathrm{SBP}(\mathrm{mm} \mathrm{Hg})$ & $151 \pm 21^{3}$ & $143 \pm 21^{2}$ & $154 \pm 20^{1,3}$ & $131 \pm 19$ \\
\hline$D B P(m m ~ H g)$ & $70 \pm 10^{3}$ & $81 \pm 12$ & $79 \pm 9^{3}$ & $85 \pm 12$ \\
\hline FBG $(\mathrm{mmol} / \mathrm{l})$ & $8.81 \pm 2.61^{3}$ & $8.73 \pm 2.15^{3}$ & $8.86 \pm 2.81^{3}$ & $5.42 \pm 0.68$ \\
\hline$H b A_{l c}(\%)$ & $5.98 \pm 1.44^{3}$ & $5.80 \pm 1.47^{3}$ & $6.07 \pm 1.43^{3}$ & $3.4 \pm 0.39$ \\
\hline TC $(\mathrm{mmol} / \mathrm{l})$ & $4.77 \pm 0.93^{3}$ & $4.83 \pm 0.90^{3}$ & $4.73 \pm 0.95^{3}$ & $5.35 \pm 0.86$ \\
\hline$T A G(\mathrm{mmol} / \mathrm{l})$ & $1.84 \pm 1.22$ & $1.87 \pm 0.83$ & $1.82 \pm 1.38$ & $1.91 \pm 1.49$ \\
\hline$L D L(\mathrm{mmol} / \mathrm{l})$ & $2.68 \pm 0.77^{3}$ & $2.76 \pm 0.75^{3}$ & $2.64 \pm 0.78^{3}$ & $3.76 \pm 0.79$ \\
\hline HDL (mmol/l) & $1.25 \pm 0.29^{3}$ & $1.22 \pm 0.25^{3}$ & $1.26 \pm 0.31^{3}$ & $1.46 \pm 0.42$ \\
\hline Creatinine $(\mu \mathrm{mol} / \mathrm{l})$ & $76.66 \pm 16.44^{3}$ & $70.68 \pm 11.28^{2}$ & $79.50 \pm 17.79^{1,3}$ & $68.65 \pm 12.54$ \\
\hline$A G E s$ (AU/g proteins) & $199.25 \pm 35.68^{3}$ & $176.09 \pm 29.35^{2,3}$ & $209.66 \pm 33.51^{1,3}$ & $144.31 \pm 27.68$ \\
\hline$A O P P(\mu \mathrm{mol} / l)$ & $124.78 \pm 39.55^{3}$ & $124.51 \pm 41.35^{3}$ & $124.90 \pm 39.21^{3}$ & $57.97 \pm 10.97$ \\
\hline LPO $(\mathrm{nmol} / \mathrm{ml})$ & $49.93 \pm 18.79$ & $54.68 \pm 20.72$ & $47.50 \pm 17.46$ & $43.95 \pm 15.48$ \\
\hline$I L-6(p g / m l)$ & $1.74 \pm 0.11^{3}$ & $1.75 \pm 0.19^{3}$ & $1.74 \pm 0.14^{3}$ & $1.36 \pm 0.12$ \\
\hline
\end{tabular}

DM2 patients - patients with type 2 diabetes mellitus, -DC - diabetic patients without diabetic complications, +DC - diabetic patients with diabetic complications, Controls - control group, SBP - systolic blood pressure, DPB - diastolic blood pressure, FBG - fasting blood glucose level, $\mathrm{HbA}_{1 \mathrm{c}}$ - glycated hemoglobin, TC - total cholesterol, TAG - triacylglycerols, LDL - low density lipoproteins, HDL - high density lipoproteins, AGEs - advanced glycation end-products, AOPP - advanced oxidation protein products, LPO - lipoperoxides, IL-6 interleukin-6, $n-$ number of subjects per group. Data are presented as means \pm S.D. of $n=81$ diabetics patients $(-D C n=26,+D C n=55)$ and $n=20$ controls. ${ }^{1} p<0.05$ compared to group $-D C,{ }^{2} p<0.05$ compared to group $+D C,{ }^{3} p<0.05$ compared to controls

\section{Results}

Comparison of clinical and biochemical parameters

Patients in -DC group had significantly higher BMI in comparison with controls (-DC vs. controls: $32.18 \pm 6.01$ vs. $28.41 \pm 5.06 \mathrm{~kg} / \mathrm{m}^{2}, \mathrm{p}=0.020$ ). Patients in + DC group had significantly higher waist circumference in comparison with controls ( $+\mathrm{DC}$ vs. controls: $104.9 \pm 13.5$ vs. $96.9 \pm 13.99 \mathrm{~cm}, \mathrm{p}=0.028)$ (Table 1$)$.

Patients in + DC group had significantly higher SBP in comparison with controls (+DC vs. controls: $154 \pm 20$ vs. $131 \pm 19 \mathrm{~mm} \mathrm{Hg}, \quad \mathrm{p}<0.0001)$ and in comparison with - DC group (+DC vs. - DC: $154 \pm 20$ vs. $143 \pm 21 \mathrm{~mm} \mathrm{Hg}, \mathrm{p}=0.015)$. We found significantly lower DBP in + DC group in comparison with controls ( + DC vs. controls: $79 \pm 9$ vs. $85 \pm 12 \mathrm{~mm} \mathrm{Hg}, \mathrm{p}=0.011$ ) (Table 2).

We observed significantly higher fasting blood glucose (FBG) and HbA1c levels in both diabetic groups in comparison with controls ( $+\mathrm{DC}$ vs. controls: FBG $8.86 \pm 2.81$ vs. $5.42 \pm 0.68 \mathrm{mmol} / \mathrm{l}$, HbA1c $6.07 \pm 1.43$ vs. $3.4 \pm 0.39 \%$; - DC vs. controls: FBG $8.73 \pm 2.15$ vs. $5.42 \pm 0.68 \mathrm{mmol} / \mathrm{l}, \mathrm{HbA} 1 \mathrm{c} 5.80 \pm 1.47$ vs. $3.4 \pm 0.39 \%$, all $\mathrm{p}<0.0001$ ), but the differences between $-\mathrm{DC}$ and $+\mathrm{DC}$ groups were not significant (Table 2).

TC levels were significantly lower in both diabetic groups in comparison with controls $(+\mathrm{DC}$ vs. controls: $p=0.003,-D C$ vs. controls: $p=0.023)$. LDL levels were significantly lower in all diabetic groups in comparison with controls (all $\mathrm{p}<0.0001$ ). We found significantly decreased HDL levels in both groups compared to controls ( $+\mathrm{DC}$ vs. controls: $\mathrm{p}=0.033$, $-\mathrm{DC}$ vs. controls: $\mathrm{p}=0.027$ ) (Table 2).

Creatinine levels were significantly higher in $+\mathrm{DC}$ group in comparison with controls ( $+\mathrm{DC}$ vs. controls: $\mathrm{p}=0.007)$ and in comparison with $-\mathrm{DC}$ group (+DC vs. $-\mathrm{DC}: \mathrm{p}=0.022)$ (Table 2).

The plasma AGE levels were significantly higher in both diabetic groups in comparison with controls (+DC vs. controls: 209.66 \pm 33.51 vs. $144.31 \pm 27.68 \mathrm{AU} / \mathrm{g}$ proteins, $\mathrm{p}<0.0001$; $-\mathrm{DC}$ vs. controls: $176.09 \pm 29.35$ vs. $144.31 \pm 27.68 \mathrm{AU} / \mathrm{g}$ proteins, $\mathrm{p}=0.003$ ). AGEs was also significantly higher in $+\mathrm{DC}$ group vs. - DC $209.66 \pm 33.51$ vs. $176.09 \pm 29.35 \mathrm{AU} / \mathrm{g}$ proteins, $\mathrm{p}<0.0001$ ) (Table 2, Fig. 1).

We observed significantly higher plasma AOPP levels in both diabetic groups in comparison with controls (+DC vs. controls: $124.90 \pm 39.21$ vs. $57.97 \pm 10.97 \mu \mathrm{mol} / 1$, -DC vs. controls: $124.51 \pm 41.35$ vs. $57.97 \pm 10.97 \mu \mathrm{mol} / 1$, in both $\mathrm{p}<0.0001$ ), but the difference between $-\mathrm{DC}$ and +DC was not significant (Table 2). 


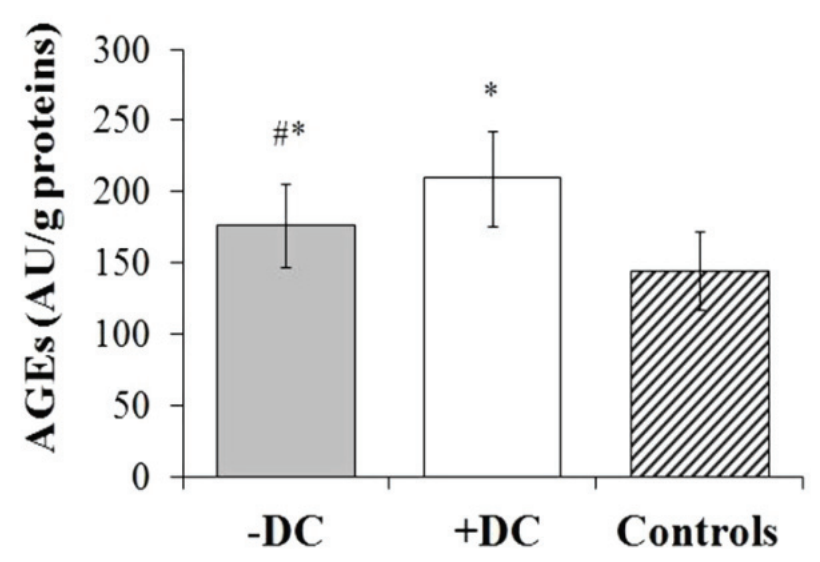

Fig. 1. Comparison of plasma AGE levels in diabetic patients and controls. AGEs - advanced glycation end-products, AU - Arbitrary Units, -DC - diabetic patients without diabetic complications, +DC - diabetic patients with diabetic complications. Values are presented as means \pm S.D. of $n=81$ diabetics patients ( $-D C n=26$, $+D C n=55)$ and $n=20$ controls. \# $p<0.05$ compared to group + DC, $* \mathrm{p}<0.05$ compared to controls

We found no significant differences in plasma LPO levels between -DC and +DC patients in comparison with controls. Also the difference between - DC and +DC patients was not significant (Table 2).

IL-6 levels were significantly increased in both diabetic groups in comparison with controls ( $+\mathrm{DC}$ vs. controls: $1.74 \pm 0.14 \mathrm{pg} / \mathrm{ml}$ vs. $1.36 \pm 0.12 \mathrm{pg} / \mathrm{ml}, \mathrm{p}=0.048$, $-\mathrm{DC}$ vs. controls: $1.75 \pm 0.19 \mathrm{pg} / \mathrm{ml}$ vs. $1.36 \pm 0.12 \mathrm{pg} / \mathrm{ml}$, $\mathrm{p}<0.05$ ). The difference between $-\mathrm{DC}$ and $+\mathrm{DC}$ was not significant (Table 2, Fig. 2).

Analysis of treatment showed that patients which were treated with OAD and OAD in combination with diet had significantly decreased levels of AGEs in comparison with patients which were treated with insulin in combination with OAD $(195.34 \pm 36.16$ resp. $164.80 \pm 32.75$. vs. $214.41 \pm 34.23 \mathrm{AU} / g$ prot.; $\mathrm{p}<0.05)$. Patients treated with OAD in combination with diet had significantly decreased levels of AOPP in comparison with patients which were treated only with OAD (101.64 \pm 43.91 vs. $135.27 \pm 40.89 \mu \mathrm{mol} / \mathrm{l} ; \mathrm{p}=0.041)$. Patients treated by hypolipidemic treatment had lower TC, TAG and LDL in comparison with controls (TC: $4.59 \pm 0.52$ vs. $5.35 \pm 0.86 \mathrm{mmol} / \mathrm{l}$; TAG: $1.49 \pm 0.72$ vs. $1.91 \pm 1.49 \mathrm{mmol} / \mathrm{l} ; \quad$ LDL: $2.55 \pm 0.76$ vs. $3.76 \pm 0.79$ mmol/l); $\quad \mathrm{p}<0.05)$. Patients without hypolipidemic treatment had higher LPO in comparison with controls (55.27 \pm 20.67 vs. $43.95 \pm 15.48 \mathrm{nmol} / \mathrm{ml}$; $<<0.05)$.

Correlations between clinical and biochemical parameters

The plasma AGE levels significantly correlated with BMI ( $\mathrm{r}=0.400, \mathrm{p}=0.007)$, with FBG ( $\mathrm{r}=0.524$,

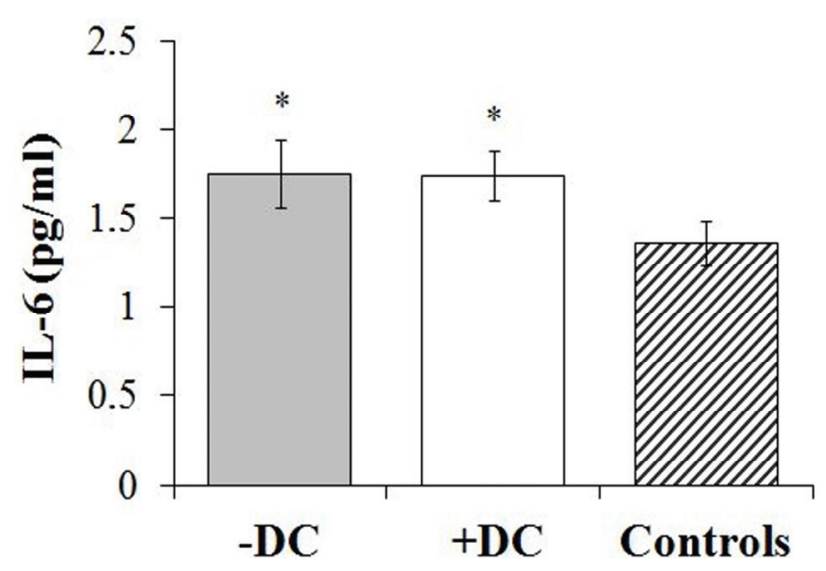

Fig. 2. Comparison of plasma IL-6 levels in diabetic patients and controls. IL-6 - interleukin-6, -DC - diabetic patients without diabetic complications, $+D C$ - diabetic patients with diabetic complications. Values are represented as means \pm S.D. of $n=81$ diabetics patients ( $-D C n=26,+D C n=55$ ) and $n=20$ controls. $* \mathrm{p}<0.05$ compared to controls

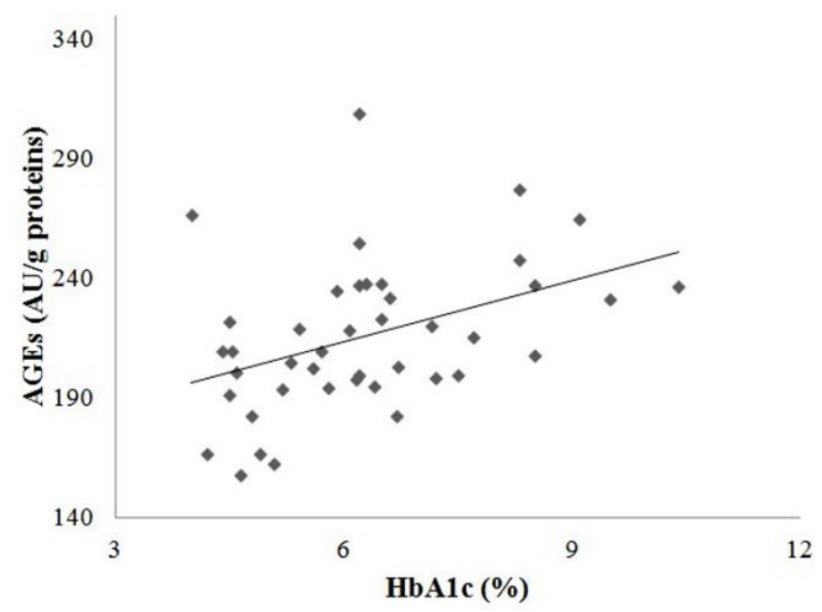

Fig. 3. Correlation between plasma AGEs and HbA1c in $+D C$ group ( $r=0.477, p=0.0005)$. AGEs - advanced glycation endproducts, HbA1c - glycated hemoglobin, AU - Arbitrary Units, $+\mathrm{DC}$ - diabetic patients with diabetic complications

$\mathrm{p}=0.0001)$, with HbA1c $(\mathrm{r}=0.477, \mathrm{p}=0.0005)$ (Fig. 3) and with TAG ( $\mathrm{r}=0.295, \mathrm{p}=0.0422)$ in $+\mathrm{DC}$ group, but not in -DC group and in controls.

The plasma LPO levels significantly correlated with BMI ( $\mathrm{r}=0.438, \mathrm{p}=0.003)$ (Fig. 4) and with waist circumference $(r=0.438, p=0.0033)$ only in $+D C$ group. LPO levels significantly correlated with FBG in both diabetic groups and in controls ( $-\mathrm{DC}: \mathrm{r}=0.528, \mathrm{p}=0.0081$, +DC: $\mathrm{r}=0.337, \mathrm{p}=0.0108$, controls: $\mathrm{r}=0.596, \mathrm{p}=0.019$ ). LPO levels significantly correlated also with TAG in both diabetic groups and in controls ( $-\mathrm{DC}: \mathrm{r}=0.600, \mathrm{p}=0.0026$, $+\mathrm{DC}: \mathrm{r}=0.371, \mathrm{p}=0.0132$, controls: $\mathrm{r}=0.875, \mathrm{p}<0.0001$ ). LPO levels inversely correlated with HDL in -DC group and in controls ( $-\mathrm{DC}$ : $\mathrm{r}=-0.510, \mathrm{p}=0.0151$, controls: $\mathrm{r}=-0.521, \mathrm{p}=0.0462)$. 


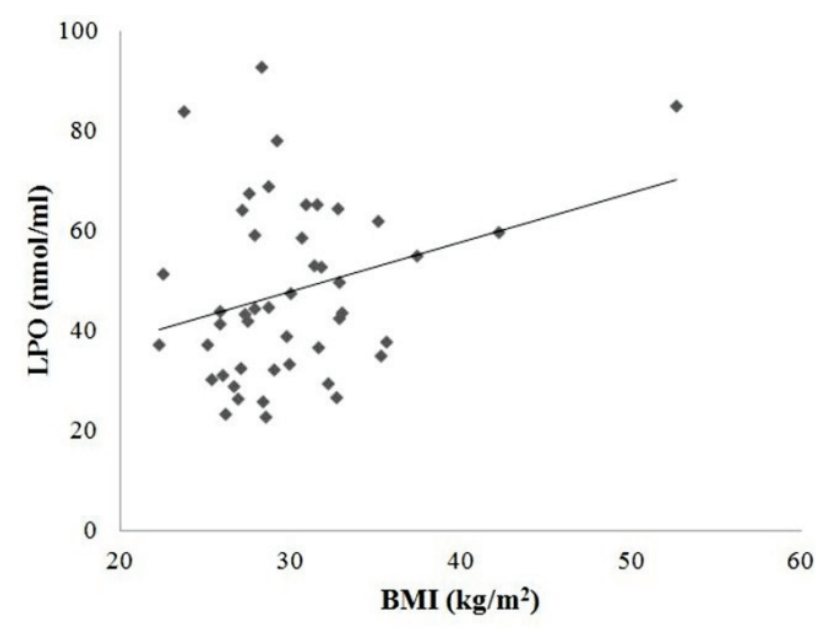

Fig. 4. Correlation between plasma $L P O$ and $B M I$ in $+D C$ group $(r=0.438, p=0.003)$. BMI - body mass index, LPO lipoperoxides, $+\mathrm{DC}$ - diabetic patients with diabetic complications

The plasma AOPP levels significantly correlated with FBG in $-\mathrm{DC}$ group ( $\mathrm{r}=0.484, \mathrm{p}=0.0374)$, but not in $+\mathrm{DC}$ group or in controls.

There was no significant correlations between IL-6 and clinical and biochemical parameters.

Evaluation of the relationship between AGEs and clinical and biochemical parameters was performed using a multivariate linear regression analysis in which AGEs were included as the dependent variable. All variables listed in Tables 1 and 2 were considered as independent variables. The significant predictors of AGEs were HbAlc $(\beta=0.507 ; p=0.0001)$ and TAG $(\beta=0.336 ; p=0.004)$ in all diabetic patients $\left(R^{2}=0.38\right)$, HbA1c $(\beta=0.514 ; \quad p=0.0013)$ and TAG $(\beta=0.389$; $\mathrm{p}=0.011)$ in $+\mathrm{DC}$ patients $\left(\mathrm{R}^{2}=0.47\right)$, and HbA1c $(\beta=0.539 ; p=0.0256)$ in $-D C$ patients $\left(R^{2}=0.41\right)$.

\section{Discussion}

Chronic microvascular DC, including retinopathy, neuropathy, nephropathy, and macrovascular disease, are the major cause of morbidity and mortality in DM2 patients (Nolan et al. 2011, Chilelli et al. 2013). Dysfunction of the key cells responsible for vascular function can be induces by increased cellular concentrations of glucose during hyperglycemia. This can activate multiple pathways of biochemical dysfunction leading to increased glycative and oxidative stress and inflammation with subsequent direct tissue damage (Yan et al. 2008, Al-Shabrawey and Smith 2010, Nguyen et al. 2012, Vlassara et al. 2012, Motawi et al. 2013, Yamamoto and Yamamoto 2013).
We have found only a few studies investigating clinical and biochemical parameters together with parameters of glycation, glycoxidation, oxidative stress and inflammation of patients with DM2 regard to the presence of DC.

HbA1c has achieved importance in diabetes because of its value in the evaluation of glucose control in clinical practice and its relation to long-term microvascular complications. This was shown for DM2 patients in the United Kingdom Prospective Diabetes Study (UKPDS Group 1998). The relationship between HbAlc and macrovascular disease appears to be more complex. A large body of observational studies, including the UKPDS, has documented increased incidence of cardiovascular and peripheral vascular disease with increased HbA1c. However ACCORD trial (Action to Control Cardiovascular Risk in Diabetes) no significant improvements in cardiovascular outcomes were achieved with further improvements in HbAlc (The ACCORD Group 2008).

HbA1c has gained acceptance as an accurate index of long-term blood glucose control. Longitudinal studies have shown that good metabolic control, reflected by stable HbA1c level, can prevent or postpone microand macrovascular and other complications or slow down the progress of DC (Zoungas et al. 2012, Penno et al. 2013). In the present study, we observed significantly higher HbA1c levels in both diabetic groups in comparison with controls, but the difference between $-D C$ group and +DC group was not significant. Therefore it would be beneficial to find also additional predictors of DC.

The preclinical and clinical studies of the last years demonstrated a close participation of AGEs in all of the micro- and macrovascular complications of diabetes, especially in type 2 diabetes mellitus (Chilelli et al. 2013). In accordance with some other studies we detected significantly increased plasma AGEs in +DC patients compared to controls (Kilhovd et al. 1999, Kiuchi et al. 2001, de la Maza et al. 2012, Kerkeni et al. 2012, Bansal et al. 2013).

In our study the plasma AGE levels in diabetic patients $+\mathrm{DC}$ were significantly higher in comparison with -DC group. In contrast, Abou-Seif and Youseff (2004) investigated not significant differences in AGEs between $+\mathrm{DC}$ and $-\mathrm{DC}$ patients. We suppose that the possible explanation is that in study of Abou-Seif and Youssef (2004) were studied only OAD treated patients and patients with microvascular complications. However, 
in our study we have included patients treated also with insulin and with macrovascular complications. We found the significant correlation between plasma AGE levels and $\mathrm{HbA} 1 \mathrm{c}$ only in $+\mathrm{DC}$ patients. No similar associations were found in -DC patients. Bansal et al. (2013) also showed positive correlation between plasma AGE levels and $\mathrm{HbA} 1 \mathrm{c}$ in DM2 patients with vascular DC.

Studies evaluating relationship between DM2 and oxidative stress, especially in micro- and macrovascular complications in detail are discussed in review of Bandeira et al. (2013). In our study AOPP levels showed the most expressive raise in plasma of + DC and -DC diabetic patients compared to controls, but no significant differences between $-\mathrm{DC}$ and $+\mathrm{DC}$ groups were observed. Others studies also reported about no significant AOPP differences between DM2 patients with micro- or macrovascular complications (Kalousová et al. 2002, Abou-Seif and Youssef 2004). Kaneda et al. (2002) suggested that AOPP is an independent risk factor for coronary artery disease. According Piwowar et al. (2007) plasma AOPP levels seem to be considered as a useful marker to estimate oxidative protein damage in diabetic patients. Gradinaru et al. (2013) in their study suggested that AOPP appear to be important biomarker for evaluating the association between diabetes and atherosclerotic disorders. They excluded patients with BMI $>25 \mathrm{~kg} / \mathrm{m}^{2}$, lipid-lowering therapy or using insulin treatment. In our study these criteria were not excluded and we suppose that they could influence our results.

Dyslipidemia, which affects almost $50 \%$ of DM2 patients, is a cardiovascular risk factor characterized by elevated TAG levels, low HDL levels, and a preponderance of LDL particles. Number of lipid lowering agents, including statins, fibrates, niacin and bile acid sequestrants, are available to target normalization of the entire lipid profile. Despite use of combination and high-dose lipid lowering agents, many DM2 patients did not achieve lipid target (Vaverková 2000, Niemeijer-Kanters et al. 2001, Mooradian 2009, Vijayaraghavan 2010, Kaefer et al. 2012). In our study TC, LDL and HDL levels were significantly lower in both diabetic groups in comparison with controls. TAG levels were similar to controls. Long-term treatment of DM2 (oral antidiabetic agents, insulin, lipid or cholesterol lowering drugs and antihypertensive drugs) optimize lipid profile (Hayashi et al. 2006, Mooradian 2009, SánchezQuesada et al. 2012) and seems to be probably helpful to prevent lipoperoxidation. In our study LPO levels in diabetic patients were similar to controls. We found the close relationship between plasma LPO with TAG in all groups. We found also significant correlation between LPO and BMI in +DC patients. Also in study of Chittar et al. (1994) were LPO significantly influenced by BMI in diabetic patients with DC. LPO also positively correlated with TAG and BMI in obese subjects (Hadwan et al. 2011).

In individuals with impaired glucose tolerance, DM2 or the metabolic syndrome, serum IL-6 levels were found to be higher compared with those with normal glucose tolerance (Pickup et al. 1997, Müller et al. 2002). Many clinical studies suggest that acute hyperglycemia can result in elevated levels of circulating proinflammatory cytokines, in particular TNF- $\alpha$, IL-6 and IL-18 (Esposito et al. 2002, Wellen and Hotamishigil 2005, van den Oever et al. 2010). Tuladhar et al. (2012) found impact of glycemic status as indicated by $\mathrm{HbAlc}$ on inflammation process in DM2 patients. The proinflammatory cytokine IL-6 may modulate the onset and progression of DC (Galassetti et al. 2006, Tunes et al. 2010). While the role of IL-6 and other pro- and antiinflammatory cytokines in the evolution of diabetes is still incompletely defined, the evidence of Galassetti et al. (2006) suggests that the simultaneous presence of diabetes may result in inappropriately elevated IL-6 levels, with potentially negative implications on the onset and progression of DC. Experimental, clinical and epidemiological studies suggest that some processes related to low-grade inflammation may be relevant to diabetic micro- and macroangiopathy (Zozulinska and Wierusz-Wysocka 2005). In our study were found significantly increased IL-6 levels in both diabetic groups compared to controls, but no significant correlation between circulating IL- 6 and parameters of early and advanced glycation and oxidative stress. However, these results do not exclude the association between IL-6 and onset of DC. Furthermore, the measurement of IL-6 in plasma should be studied as adjunct to HbAlc monitoring.

We suggest that the measurement not only HbA1c, but also fluorescent AGEs in plasma may be useful to predict the risk of DC development at a primary care setting. The spectrofluorimetric technique for AGEs and spectrophotometric technique for markers of oxidative stress (AOPP, LPO) used in our study are simple, fast and inexpensive so they can be applicable on large sample size analysis in current laboratory practice, for evaluating glycative and oxidative stresses. We were searching for valuable biomarker for evaluation of the 
risk of DC development. From this point of view among used markers we propose measurement of fluorescent AGEs as valuable biomarker in clinical practice for prediction of diabetic complications. Furthermore, the measurement of AOPP, LPO and IL-6 in plasma should be studied as markers of oxidative stress and inflammation, but not to predict of DC development.

\section{Conflict of Interest}

There is no conflict of interest.

\section{Acknowledgements}

This work was supported by grants VEGA 1-0375-09, VEGA 1-0451-12 and Grant UK 492/2012.

\section{References}

ABOU SEIF MA, YOUSSEF AA: Evaluation of some biochemical changes in diabetic patients. Clin Chim Acta 346: 161-170, 2004.

AL-SHABRAWEY M, SMITH S: Prediction of diabetic retinopathy: role of oxidative stress and relevance of apoptotic biomarkers. EPMA J 1: 56-72, 2010.

ARONSON D: Hyperglycemia and pathobiology of diabetic complications. Adv Cardiol 45: 1-16. 2008.

BANDEIRA SM, FONSECA LJS, GUEDES GS, RABELO LA, GOULART MOF, VASCONCELOS SML: Oxidative stress as an underlying contributor in the development of chronic complications in diabetes mellitus. Int J Mol Sci 14: 3265-3284, 2013.

BANSAL S, CHAWLA D, SIDDARTH M, BANERJEE BD, MADHU SV, TRIPATHI AK: A study on serum advanced glycation end products and its association with oxidative stress and paraoxonase activity in type 2 diabetic patients with vascular complications. Clin Biochem 46: 109-114, 2013.

BARBARROJA N, LOPEZ-PEDRERA C, GARRIDO-SANCHEZ L, MAYAS MD, OLIVA-OLIVERA W, BERNAL-LOPEZ MR, EL BEKAY R, TINAHONES FJ: Progression from high insulin resistance to type 2 diabetes does not entail additional visceral adipose tissue inflammation. PLoS One 7: e48155, 2012.

BASTOS AS, GRAVES DT, LOUREIRO AP, ROSSA JÚNIOR C, ABDALLA DS, FAULIN T DO E, OLSEN CÂMARA N, ANDRIANKAJA OM, ORRICO SR: Lipid peroxidation is associated with the severity of periodontal disease and local inflammatory markers in patients with type 2 diabetes. J Clin Endocrinol Metab 97: E1353-E1362, 2012.

BIGAGLI E, RAIMONDI L, MANNUCCI E, COLOMBI C, BARDINI G, ROTELLA CM, LODOVICI M: Lipid and protein oxidation products, antioxidant status and vascular complications in poorly controlled type 2 diabetes. BJDVD 12: 33-39, 2012.

CALDER PC, AHLUWALIA N, BROUNS F, BUETLER T, CLEMENT K, CUNNINGHAM K, ESPOSITO K, JÖNSSON LS, KOLB H, LANSINK M, MARCOS A, MARGIORIS A, MATUSHESKI N, NORDMANN H, O'BRIEN J, PUGLIESE G, RIZKALLA S, SCHALKWIJK C, TUOMILEHTO J, WÄRNBERG J, WATZL B, WINKLHOFER-ROOB BM: Dietary factors and low-grade inflammation in relation to overweight and obesity. Br J Nutr 106: 5-78, 2011.

CARMAN TL, FERNANDEZ BB Jr: A primary care approach to the patient with claudication. Am Fam Physician 61: 1027-1032, 2000.

CHEN M, CURTIS TM, STITT AW: Advanced glycation end products and diabetic retinopathy. Curr Med Chem 20: 3234-3240, 2013.

CHILELLI NC, BURLINA S, LAPOLLA A: AGEs, rather than hyperglycemia, are responsible for microvascular complications in diabetes: A "glycoxidation-centric" point of view. Nutr Metab Cardiovasc Dis 23: 913-919, 2013.

CHITTAR HS, NIHALANI KD, VARTHAKAVI PK, UDIPI AS: Lipid peroxide levels in diabetics with micro- and macro-angiopathies. J Nutr Biochem 5: 442-445, 1994.

DE LA MAZA MP, GARRIDO F, ESCALANTE N, LEIVA L, BARRERA G, SCHNITZLER S, ZANOLLI M, VERDAGUER J, HIRSCH S, JARA N, BUNOUT D: Fluorescent advanced glycation end-products (ages) detected by spectro-photofluorimetry, as a screening tool to detect diabetic microvascular complications. JDM 2: 221-226, 2012. 
DE REKENEIRE N, PEILA R, DING J, COLBERT LH, VISSER M, SHORR RI, KRITCHEVSKY SB, KULLER LH, STROTMEYER ES, SCHWARTZ AV, VELLAS B, HARRIS TB: Diabetes, hyperglycemia, and inflammation in older individuals: the health, aging and body composition study. Diabetes Care 29: 1902$1908,2006$.

EL-SAADANI M, ESTERBAUER H, EL-SAYED M, GOHER M, NASSAR AY, JÜRGENS G: A spectrophotometric assay for lipid peroxides in serum lipoproteins using a commercially available reagent. J Lipid Res 30: 627 630, 1989.

ESPOSITO K, NAPPO F, MARFELLA R, GIUGLIANO G, GIUGLIANO F, CIOTOLA M, QUAGLIARO L, CERIELLO A, GIUGLIANO D: Inflammatory cytokine concentrations are acutely increased by hyperglycemia in humans: role of oxidative stress. Circulation 106: 2067-2072, 2002.

GALASSETTI PR, IWANAGA K, PONTELLO AM, YALDIVAR FP, FLORES RL, LARSON JK: Effect of prior hyperglycemia on IL-6 responses to exercise in children with type 1 diabetes. Am J Physiol 290: E833-E839, 2006.

GARCIA C, FEVE B, FERRÉ P, HALIMI S, BAIZRI H, BORDIER L, GUIU G, DUPUY O, BAUDUCEAU B, MAYAUDON H: Diabetes and inflammation: fundamental aspects and clinical implications. Diabetes Metab 36: 327-338, 2010.

GARCIA SC, MORETTO MB, MORESCO RN: Plasma malondialdehyde levels and risk factors for the development of chronic complications in type 2 diabetic patients on insulin therapy. Clin Laboratory 58: 973-978, 2012.

GIACCO F, BROWNLEE M: Oxidative stress and diabetic complications. Circ Res 107: 1058-1070, 2010.

GRADINARU D, BORSA C, IONESCU C, MARGINA D: Advanced oxidative and glycoxidative protein damage markers in the elderly with type 2 diabetes. J Proteomics 92: 313-322, 2013.

HADWAN HM, ALTAEE AH, ZAIDAN HK: The levels of protein oxidation and lipid peroxidation in sera of obese men. J Babylon University 19: 105-110, 2011.

HAYASHI T, HIRANO T, YAMAMOTO T, ITO Y, ADACHI M: Intensive insulin therapy reduces small dense lowdensity lipoprotein particles in patients with type 2 diabetes mellitus: relationship to triglyceride-rich lipoprotein subspecies. Metabol Clin Exper 55: 879-884, 2006.

HEGAB Z, GIBBONS S, NEYSES L, MAMAS MA: Role of advanced glycation end products in cardiovascular disease. World J Cardiol 4: 90-102, 2012.

HENLE T, DEPPISCH R, BECK W, HERGESELL O, HÄNSCH GM, RITZ E: Advanced glycated end-products (AGE) during haemodialysis treatment: discrepant results with different methodologies reflecting the heterogeneity of AGE compounds. Nephrol Dial Transplant 14: 1968-1975, 1999.

HIGGINS T: HbA1c for screening and diagnosis of diabetes mellitus. Endocrine 43: 266-273, 2013.

JAKUS V, RIETBROCK N: Advanced glycation end-products and the progress of diabetic vascular complications. Phys Res 53: 131-142, 2004.

JEFFCOATE WJ, GAME F, CAVANAGH PR: The role of proinflammatory cytokines in the cause of neuropathic osteoarthropathy (acute Charcot foot) in diabetes. Lancet 336: 2058-2061, 2006.

KAEFER M, DE CALVAlHo JAM, PIVA SJ, DA SILVA DB, BECKER AM, SANGOI MB, ALMEIDA TC, HERMES CL, COELHO AC, TONELLO R, MOREIRA APL, GARCIA SC, MORETTO MB, MORESCO $\mathrm{RN}$ : Plasma malondialdehyde levels and risk factors for the development of chronic complications in type 2 diabetic patients on insulin therapy. Clin Laboratory 58: 973-978, 2012.

KALOUSOVÁ M, ZIMA T, TESǍ̌ V, ŠTÍPEK S: New markers of advanced damage caused by oxidative and carbonyl stress (in Czech). Sb lek 102: 465-472, 2001.

KALOUSOVÁ M, ŠKRHA J, ZIMA T: Advanced glycation end-products and advanced oxidation protein products in patients with diabetes mellitus. Physiol Res 51: 597-604, 2002.

KANEDA H, TAGUCHI J, OGASAWARA K: Increased level of advanced oxidation protein products in patients with coronary artery disease. Atherosclerosis 162: 221-225, 2002.

KERKENI M, SAIDI A, BOUZIDI H, LETAIEF A, BEN YAHIA S, HAMMAMI M: Pentosidine as a biomarker for microvascular complications in type 2 diabetic patients. Diab Vasc Dis Res 10: 239-245, 2012.

KHAN TH, FAROOQUI FA, NIAZI K: Critical review of the ankle brachial index. Curr Cardiol Rev 4: 101-106, 2008. 
KILHOVD BK, BERG TJ, BIRKELAND KI, THORSBY P, HANSSEN KF: Serum levels of advanced glycation end products are increased in patients with type 2 diabetes and coronary heart disease. Diab Care 22: 1543-1548, 1999.

KING GL: The role of inflammatory cytokines in diabetes and its complications. J Periodontol 79: 1527-1534, 2008.

KIUCHI K, NEJIMA J, TAKANO T, OHTA M, HASHIMOTO H: Increased serum concentrations of advanced glycation end products: a marker of coronary artery disease activity in type 2 diabetic patients. Heart 85: 8791, 2001.

LITTLE JA: Comparison of curve fitting models for ligand binding assays. Chromatographia 59: S177-S181, 2004.

MILLER AD, NONAKA S, JAKUŠ J: Modulation of vomiting by the medullary midline. Brain Res 737: 51-58, 1996.

MOCAN MC, KADAYIFCILAR S, ELDEM B: Elevated intravitreal interleukin-6 levels in patients with proliferative diabetic nephropathy. Can J Ophtalmol 41: 747-752, 2006.

MOORADIAN AD: Dyslipidemia in type 2 diabetes mellitus. Nat Clin Pract Endocrinol Metab 5: 150-159, 2009.

MORA C, NAVARRO JF: Inflammation and diabetic nephropathy. Curr Diabetes Rep 6: 463-468, 2006.

MOTAWI TM, ABOU-SEIF MA, BADER AM, MAHMOUD MO: Effect of glycemic control on soluble RAGE and oxidative stress in type 2 diabetic patients. BMC Endocr Disord 13: 32, 2013.

MÜLLER S, MARTIN S, KOENIG W, HANIFI-MOGHADDAM P, RATHMANN W, HAASTERT B, GIANI G, ILLIG T, THORAND B, KOLB H: Impaired glucose tolerance is associated with increased serum concentrations of interleukin-6 and co-regulated acute-phase proteins but not TNF- $\alpha$ or its receptors. Diabetologia 45: 805-812, 2002.

MÜNCH G, KEIS R, WESSELS A, RIEDERER P, BAHNER U, HEIDLAND A, NIWA T, LEMKE HD, SCHINZEL R: Determination of advanced glycation end products in serum by fluorescence spectroscopy and competitive ELISA. Eur J Clin Chem Clin Biochem 35: 669-677, 1997.

NAVALE AM, PARANJAPE AN: Role of inflammation in development of diabetic complications and commonly used inflammatory markers with respect to diabetic complications. Int J Pharm Sci 5: 1-5, 2013.

NEGRE-SALVAYRE A, SALVAYRE R, AUGE N, PAMPLONA R, PORTERO-OTIN M: Hyperglycemia and glycation in diabetic complications. Antioxid Redox Signal 11: 3071-3109, 2009.

NGUYEN DV, SHAW LC, GRANT MB: Inflammation in the pathogenesis of microvascular complications in diabetes. Front Endocrinol (Lausanne) 21: 1-7, 2012.

NICE CLINICAL GUIDELINES, NO. 73: Chronic Kidney Disease: National Clinical Guideline for Early Identification and Management in Adults in Primary and Secondary Care. The National Collaborating Centre for Chronic Conditions, Royal College of Physicians (UK), London, 2008, p. 39.

NIEMEIJER-KANTERS SD, BANGA JD, ERKELENS DW: Lipid-lowering therapy in diabetes mellitus. Neth J Med 58: 214-222, 2001.

NOLAN CJ, DAMM P, PRENTKI M: Type 2 diabetes across generations: from pathophysiology to prevention and management. Lancet 378: 169-181, 2011.

PANENI F, BECKMAN JA, CREAGER MA, COSENTINO F: Diabetes and vascular disease: pathophysiology, clinical consequences, and medical therapy: part I. Eur Heart J 34: 2436-2446, 2013.

PEDICINO D, LIUZZO G, TROTTA F, GIGLIO AF, GIUBILATO S, MARTINI F, ZACCARDI F, SCAVONE G, PREVITERO M, MASSARO G, CIALDELLA P, CARDILLO MT, PITOCCO D, GHIRLANDA G, CREA F: Adaptive immunity, inflammation, and cardiovascular complications in type 1 and type 2 diabetes mellitus. J Diabetes Res 2013: 184258, 2013.

PENNO G, SOLINI A, ZOPPINI G, ORSI E, FONDELLI C, ZERBINI G, MORANO S, CAVALOT F, LAMACCHIA O, TREVISAN R, VEDOVATO M, PUGLIESE G; RENAL INSUFFICIENCY AND CARDIOVASCULAR EVENTS (RIACE) STUDY GROUP: Hemoglobin A1c variability as an independent correlate of cardiovascular disease in patients with type 2 diabetes: a cross-sectional analysis of the renal insufficiency and cardiovascular events (RIACE) Italian multicenter study. Cardiovasc Diabetol 12: 1-13, 2013.

PIARULLI F, SARTORE G, LAPOLLA A: Glyco-oxidation and cardiovascular complications in type 2 diabetes: a clinical update. Acta Diabetol 50: 101-110, 2013. 
PICKUP JC, MATTOCK MB, CHUSNEY GD, BURT D: NIDDM as a disease of the innate immune system: association of acute-phase reactants and interleukin-6 with metabolic syndrome X. Diabetologia 40: 12861292, 1997.

PIWOWAR, A., KNAPIK-KORDECKA, M., WARWAS, M: AOPP and its relations with selected markers of oxidative/antioxidative system in type 2 diabetes mellitus. Diabetes Res Clin Pract 77: 188-192, 2007.

RÁCZ O, KUZMOVÁ D, LEPEJOVÁ K, DOMBROVSKÝ P: HbA1c - endless story (in Slovak)? Labor Aktuell 1: 24-28, 2012.

SÁNCHEZ-QUESADA JL, VINAGRE I, DE JUAN-FRANCO E, SÁNCHEZ-HERNÁNDEZ J, BLANCO-VACA F, ORDÓŇEZ-LLANOS J, PÉREZ A: Effect of improving glycemic control in patients with type 2 diabetes mellitus on low-density lipoprotein size, electronegative low-density lipoprotein and lipoprotein-associated phospholipase A2 distribution. Am J Cardiol 110: 67-71, 2012.

SHI XY, HOU FF, NIU HX, WANG GB, XIE D, GUO ZJ, ZHOU ZM, YANG F, TIAN JW, ZHANG X: Advanced oxidation protein products promote inflammation in diabetic kidney through activation of renal nicotinamide adenine dinucleotide phosphate oxidase. Endocrinology 149: 1829-1839, 2008.

SINGH R, KAUR N, KISHORE L, KUMAR GUPTA G: Management of diabetic complications: a chemical constituents based approach. J Ethnopharmacol 150: 51-70, 2013.

SUMEGOVÁ K, BLAŽÍČEK P, WACZULÍKOVÁ I, ŽITŇANOVÁ I, ĎURAČKOVÁ Z: Activity of paraoxonase 1 (PON1) and its relationship to markers of lipoprotein oxidation in healthy Slovaks. Acta Biochim 53: 783-787, 2006.

THE ACTION TO CONTROL CARDIOVASCULAR RISK IN DIABETES STUDY (ACCORD) GROUP: Effects of intensive glucose lowering in type 2 diabetes. $N$ Engl J Med 358: 2545-2559, 2008.

TULADHAR ET, SHARMA VK, SIGDEL M, SHRESTHA L: Type 2 diabetes mellitus with early phase acute inflammatory protein on serum protein electrophoresis. J Patology Nepal 2: 212-214, 2012.

TUNES RS, FOSS-FREITAS MC, ROCHA NOGUEIRA-FILHO GDA R: Impact of periodontitis on the diabetesrelated inflammatory status. $J$ Can Dent Assoc 76: 1-7, 2010.

UK PROSPECTIVE DIABETES STUDY (UKPDS) GROUP: Effect of intensive blood-glucose control with metformin on complications in overweight patients with type 2 diabetes (UKPDS 34). Lancet 352: 854-865, 1998.

VAN DEN OEVER IA, RATERMAN HG, NURMOHAMED MT, SIMSEK S: Endothelial dysfunction, inflammation, and apoptosis in diabetes mellitus. Mediators Inflamm 2010: 792393, 2010.

VAVERKOVÁ H: Dyslipoproteinemia and diabetes mellitus (in Czech). Vnitr Lek 46: 532-538, 2000.

VIGNALI DA: Multiplexed particle-based flow cytometric assays. J Immunol Methods 243: 243-255, 2000.

VIJAYARAGHAVAN K: Treatment of dyslipidemia in patients with type 2 diabetes. Lipids Health Dis 9: 144, 2010.

VLASSARA H, URIBARRI J, CAI W, GOODMAN S, PYZIK R, POST J, GROSJEAN F, WOODWARD M, STRIKER GE: Effects of sevelamer on HbAlc, inflammation, and advanced glycation end products in diabetic kidney disease: Clin J Am Soc Nephrol 7: 934-942, 2012.

WADHAM C, PARKER A, WANG L, XIA P: High glucose attenuates protein S-nitrosylation in endothelial cells. Role of oxidative stress. Diabetes 11: 2715-2721, 2007.

WANG X, BAO W, LIU J, OUYANG YY, WANG D, RONG S, XIAO X, SHAN ZL, ZHANG Y, YAO P, LIU LG: Inflammatory markers and risk of type 2 diabetes: a systematic review and meta-analysis. Diabetes Care 36: 166-175, 2013.

WELLEN KE, HOTAMISHIGIL GS: Inflammation, stress and diabetes. J Clin Invest 115: 1111-1119, 2005.

WILLIAMS MD, NADLER JL: Inflammatory mechanisms of diabetic complications. Curr Diab Rep 7: 242-248, 2007.

WITKO-SARSAT V, FRIEDLANDER M, CAPEILLÈRE-BLANDIN C, NGUYEN-KHOA T, NGUYEN AT, ZINGRAFF J, JUNGERS P, DESCAMPS-LATSCHA B: Advanced oxidation protein products as a novel marker of oxidative stress in uremia. Kidney Int 49: 1304-1313, 1996.

WU W, WANG M, SUN Z, WANG X, MIAO J, ZHENG Z: The predictive value of TNF-alfa and IL-6 and the incidence of macrovascular complications in patients with type 2 diabetes. Acta Diabetol 49: 3-7, 2012.

YADAV UC, RAMANA KV: Regulation of NF-kB-induced inflammatory signaling by lipid peroxidation-derived aldehydes. Oxid Med Cell Longev 2013: 690545, 2013. 
YAMAMOTO Y, YAMAMOTO H: RAGE-mediated inflammation, type 2 diabetes, and diabetic vascular complication. Front Endocrinol (Lausanne) 4: 105, 2013.

YAN SF, RAMASAMY R, SCHMIDT AM: Mechanisms of disease: advanced glycation end-products and their receptor in inflammation and diabetes complications. Nat Clin Pract Endocrinol Metab 4: 285-293, 2008.

ZOUNGAS S, CHALMERS J, NINOMIYA T, LI Q, COOPER ME, COLAGIURI S, FULCHER G, DE GALAN BE, HARRAP S, HAMET P, HELLER S, MACMAHON S, MARRE M, POULTER N, TRAVERT F, PATEL A, NEAL B, WOODWARD M; ADVANCE COLLABORATIVE GROUP: Association of HbA1c levels with vascular complications and death in patients with type 2 diabetes: evidence of glycaemic thresholds. Diabetologia 55: 636-643, 2012.

ZOZULINSKA D, WIERUSZ-WYSOCKA B: Hyperglycaemia and inflammation are culprits of late diabetic complications. Arch Med Sci 1, 2: 115-118, 2005. 